\title{
A Phylogenetic Analysis of the Genus Nocardia with 16S rRNA Gene Sequences
}

\author{
JONGSIK CHUN AND MICHAEL GOODFELLOW* \\ Department of Microbiology, The Medical School, Newcastle upon Tyne NE2 4HH, United Kingdom
}

\begin{abstract}
Partial sequences of the 16S rRNA genes of the type strains of nine species of the genus Nocardia were determined following the isolation and cloning of the amplified genes. These sequences were aligned with the sequences of representatives of the genera Corynebacterium, Gordona, Mycobacterium, Rhodococcus, and Tsukamurella, and phylogenetic trees were inferred by using the Fitch-Margoliash and neighbor-joining methods. The genus Nocardia formed a distinct clade that was most closely associated with the genus Rhodococcus. The average level of sequence similarity found among the type strains of the Nocardia species was $97.2 \pm 0.7 \%$. Two sublines were recognized within the Nocardia clade; one encompassed Nocardia asteroides and related species, and the other encompassed Nocardia otitidiscaviarum and allied taxa. Separation of the two sublines is based on differences in helix 37-1. The results of isoprenoid quinone analyses provided evidence that nocardiae can be distinguished from all other actinomycete taxa on the basis of their characteristic menaquinone profiles. Nocardiae typically contain hexahydrogenated menaquinones with eight isoprene units in which the two end units are cyclized.
\end{abstract}

The taxonomy of actinomycetes that contain mycolic acids (high-molecular-weight, long-chain, 3-hydroxy fatty acids with an alkyl branch at position 2) has undergone sweeping changes on the basis of data derived from the use of modern taxonomic methods $(18,19,35)$. The mycolic acid-containing bacteria have many phenotypic characteristics in common $(6,18)$, form a distinct phyletic line (48), and have been assigned to the genera Corynebacterium, Gordona, Mycobacterium, Nocardia, Rhodococcus, and Tsukamurella on the basis of a number of chemical and morphological markers $(5,6,18,19)$. Proposals to transfer Nocardia amarae (33) to the genus Gordona as Gordona amarae (20) leave the genus Nocardia as a relatively homogeneous taxon that contains 11 validly described species $(18,21,58)$. The retention of one of these species, Nocardia pinensis, in the genus Nocardia has been debatable as this organism has many properties in common with G. amarae and can be readily distinguished from typical nocardiae (2). On the basis of $16 \mathrm{~S}$ rRNA sequence data and complementary phenotypic properties, $N$. pinensis merits generic status within the family Nocardiaceae (11).

Members of the reconstituted genus Nocardia form extensively branched substrate hyphae that fragment in situ or after mechanical disruption into rod-shaped to coccoid, nonmotile elements; aerial hyphae, which at times are visible only microscopically, are almost always formed $(21,31)$. Nocardiae are also characterized by the presence of meso-diaminopimelic acid, arabinose, and galactose in their wall peptidoglycan (wall chemotype IV sensu Lechevalier and Lechevalier [32]) (A1 $\gamma$ type), have muramic acid in the $N$-glycolated form, have diphosphatidylglycerol, phosphatidylethanolamine, phosphatidylinositol, and phosphatidylinositol mannosides as their predominant phospholipids, have major amounts of straightchain, unsaturated, and tuberculostearic acids, have mycolic acids with 40 to 60 carbon atoms, and have DNAs that are rich in guanine plus cytosine (guanine-plus-cytosine contents, 64 to $72 \mathrm{~mol} \%)(6,18,21)$. The predominant nocardial menaquinone is an unusual hexahydrogenated menaquinone with eight

\footnotetext{
${ }^{*}$ Corresponding author. Mailing address: Department of Microbiology, The Medical School, Framlington Place, Newcastle upon Tyne NE2 4HH, United Kingdom. Fax: 44-91-222-7736.
}

isoprene units in which the end two units are cyclized $(13,25$, 27).

Nocardia species have been circumscribed primarily by using chemical, numerical taxonomic, DNA relatedness, phage sensitivity, immunological, and antibiotic susceptibility data $(1,4$, $6,18,19,55,56)$, although problems remain. It is important to distinguish between different kinds of nocardiae as some nocardiae cause a variety of suppurative diseases in humans and animals, notably actinomycete mycetoma and nocardiosis (5, 51). Nocardia brasiliensis and Nocardia transvalensis are the main causal agents of actinomycete mycetoma $(35,36)$, and the predominant agents of nocardiosis are Nocardia asteroides, Nocardia farcinica, and Nocardia nova $(51,55)$.

It is necessary to examine the taxonomic structure of the genus Nocardia in order to determine the relationships among the constituent species. Ruimy et al. (48) have shown by performing ribosomal DNA (rDNA) sequence analyses that representatives of most species belonging to the genus Nocardia form a distinct phyletic line, although not all of the type strains were examined by these workers nor was much light cast on the phylogenetic relationships within the genus. The study described in this paper was an extension of the previous study of Ruimy et al., although in addition to sequence analyses the menaquinone compositions of the test strains were determined.

\section{MATERIALS AND METHODS}

Organisms and culture conditions. Cultures of the test strains (Table 1) used to prepare biomass were grown in shake flasks containing modified Sauton's broth (39); these cultures were incubated for 7 to 10 days at $30^{\circ} \mathrm{C}$. When maximum growth was observed, the broth cultures were checked for purity, killed with $1 \%$ ( vol/vol) formaldehyde, harvested by centrifugation, washed with distilled water, and freeze-dried. The nocardiae were maintained on glucose-yeast extract agar (22) slopes and as glycerol suspensions $(20 \%$, vol $/ \mathrm{vol})$ at $-20^{\circ} \mathrm{C}$.

Menaquinone analysis. Isoprenoid quinones were extracted from freeze-dried biomass $(50 \mathrm{mg})$ by using the small-scale procedure of Minnikin et al. (37). Purified menaquinones were separated by high-performance liquid chromatography, using a Pharmacia LKB instrument fitted with a Spherisorb octyldecyl silane column $(5 \mu \mathrm{m})$ and acetonitrile-isopropanol $(75: 25$, vol/vol $)$ as the mobile phase. The menaquinones were detected at $254 \mathrm{~nm}$.

DNA extraction. Chromosomal DNA was isolated by using a method modified slightly from the method of Pitcher et al. (44). Small amounts of biomass from glucose-yeast extract agar plates were mixed and gently homogenized in $1.5-\mathrm{ml}$ tubes containing $100 \mu \mathrm{l}$ of T.E. buffer ( $\mathrm{pH} 8.0$ ) supplemented with lysozyme (50 $\mathrm{mg} / \mathrm{ml}$; Sigma, Ltd., Poole, Dorset, United Kingdom). The resulting solutions 
TABLE 1. Strains used in the 16S rRNA sequence analysis

\begin{tabular}{|c|c|c|c|c|}
\hline Laboratory no. & Species & $\begin{array}{c}\text { Other } \\
\text { designation }^{a}\end{array}$ & $\begin{array}{l}\text { Nucleotide } \\
\text { sequence } \\
\text { accession no. }\end{array}$ & $\begin{array}{l}\text { Source of data } \\
\text { or reference }\end{array}$ \\
\hline$--^{b}$ & Arthrobacter globiformis & DSM $20124^{\mathrm{T}}$ & M23411 & $\mathrm{RDP}^{c}$ \\
\hline- & Corynebacterium variablis & NCIB $9455^{\mathrm{T}}$ & X53185 & RDP \\
\hline- & Corynebacterium xerosis & ATCC $373^{\mathrm{T}}$ & M59058 & RDP \\
\hline N667 & Gordona amarae & ATCC $27808^{\mathrm{T}}$ & X75902 & 20 \\
\hline - & Gordona terrae & DSM $43249^{T}$ & X53202 & RDP \\
\hline- & Mycobacterium bovis & Strain BCG & M20940 & RDP \\
\hline - & Mycobacterium smegmatis & ATCC 14468 & X52922 & RDP \\
\hline $\mathrm{N} 317^{\mathrm{T}}$ & Nocardia asteroides & ATCC $19247^{\mathrm{T}}$ & Z36934 & This study \\
\hline - & Nocardia asteroides & DSM 43005 & X57949 & RDP \\
\hline $\mathrm{N} 318^{\mathrm{T}}$ & Nocardia brasiliensis & ATCC $19296^{\mathrm{T}}$ & Z36935 & This study \\
\hline $\mathrm{N} 1201^{\mathrm{T}}$ & Nocardia brevicatena & DSM $43024^{T}$ & $\mathrm{Z} 36928$ & This study \\
\hline $\mathrm{N} 1200^{\mathrm{T}}$ & Nocardia carnea & DSM $43397^{\mathrm{T}}$ & Z36929 & This study \\
\hline $\mathrm{N} 898^{\mathrm{T}}$ & Nocardia farcinica & ATCC $3318^{\mathrm{T}}$ & Z36936 & This study \\
\hline $\mathrm{N} 1112^{\mathrm{T}}$ & Nocardia nova & $\mathrm{JCM} 6044^{\mathrm{T}}$ & Z36930 & This study \\
\hline $\mathrm{N} 36^{\mathrm{T}}$ & Nocardia otitidiscaviarum & ATCC $14629^{\mathrm{T}}$ & M59056 & RDP \\
\hline N1116 ${ }^{\mathrm{T}}$ & Nocardia seriolae & JCM $3360^{\mathrm{T}}$ & Z36925 & This study \\
\hline $\mathrm{N} 1202^{\mathrm{T}}$ & Nocardia transvalensis & DSM $43405^{T}$ & Z36926 & This study \\
\hline $\mathrm{N} 1199^{\mathrm{T}}$ & Nocardia vaccinii & DSM $43285^{\mathrm{T}}$ & Z36927 & This study \\
\hline- & Rhodococcus erythropolis & DSM $43188^{\mathrm{T}}$ & $\mathrm{X} 53203$ & RDP \\
\hline - & Rhodococcus fascians & DSM 20131 & X53204 & RDP \\
\hline N663 & Tsukamurella paurometabola & NCTC 10741 & Z36933 & 12 \\
\hline
\end{tabular}

${ }^{a}$ ATCC, American Type Culture Collection, Rockville, Md.; DSM, Deutsche Sammlung von Mikroorganismen und Zellkulturen GmbH, Braunschweig, Germany; JCM, Japan Collection of Microorganisms, Wako-Shi, Saitama, Japan; NCIB, National Collection of Industrial Bacteria, Aberdeen, United Kingdom; NCTC, National Collection of Type Cultures, Central Public Health Laboratory, Colindale, London, United Kingdom.

${ }^{b}$ - , no laboratory number assigned.

${ }^{c}$ RDP, Ribosomal Database Project, release 4 (30).

were incubated at $37^{\circ} \mathrm{C}$ overnight, and $500 \mu$ l of a guanidine-sarcosyl solution was added to each preparation. The aqueous layers were separated by centrifugation and extracted with chloroform-isoamyl alcohol $(25: 1$, vol/vol), and the chromosomal DNA was precipitated with 0.54 volume of isopropanol, washed in $70 \%$ (vol/vol) ethanol, and dried under a vacuum. The DNA samples were redissolved in $90 \mu$ l of T.E. buffer (pH 8.0), and $10 \mu \mathrm{l}$ of RNase A $(10 \mathrm{mg} / \mathrm{ml}$; Sigma) was added before the preparation was incubated at $37^{\circ} \mathrm{C}$ for $2 \mathrm{~h}$. After the RNase treatment, the DNA samples were extracted with phenol and chloroform, precipitated by adding 3 volumes of ethanol in the presence of $0.8 \mathrm{M}$ lithium chloride, washed with $70 \%$ ethanol, dried, and redissolved in $30 \mu \mathrm{l}$ of water.

PCR amplification of 16S rDNA. The 16S rRNA genes (rDNA) were amplified by using universal primers p27f (5'-AGA GTT TGA TCM TGG CTC AG-3'; positions 8 to 27; Escherichia coli numbering of Brosius et al. [7]) and p1525r (5'-AAG GAG GTG WTC CAR CC-3'; positions 1541 to 1525) (29). Each PCR mixture $(100 \mu \mathrm{l})$ contained primers (each at a concentration of $0.4 \mu \mathrm{M}$ ), a mixture of deoxynucleoside triphosphates (Boeringer Mannheim) (each at a concentration of $200 \mu \mathrm{M}$ ), and $T a q$ polymerase buffer (Hoefer Scientific Instruments, Newcastle upon Tyne, United Kingdom). Chromosomal DNA (ca. 100 $\mathrm{ng}$ ) was added to the solution, which was then heated at $98^{\circ} \mathrm{C}$ for 2 min and cooled immediately on ice. Taq polymerase $(2.5 \mathrm{U})$ and 1 drop of mineral oil (Sigma) were then added to each of the reaction solutions. The DNA thermal cycler (Omnigene; Hybaid, Ltd., Middlesex, United Kingdom) used for thermal amplification was programmed as follows: (i) an initial extensive denaturation step consisting of $94^{\circ} \mathrm{C}$ for $2 \mathrm{~min}$; (ii) 25 reaction cycles, with each cycle consisting of $94^{\circ} \mathrm{C}$ for $1 \mathrm{~min}, 55^{\circ} \mathrm{C}$ for $1 \mathrm{~min}$, and $72^{\circ} \mathrm{C}$ for $3 \mathrm{~min}$; and (iii) a final extension step consisting of $72^{\circ} \mathrm{C}$ for $10 \mathrm{~min}$.

Isolation and cloning of amplified 16S rDNA. Amplified 16S rDNA was purified from $0.8 \%$ agarose gels by using the method of Heery et al. (24). Purified rDNA was ligated into the pGEM-T vector (Promega Co., Southampton, United Kingdom) according to the manufacturer's instruction. Ligated plasmids were then transformed into $E$. coli JM109, and transformants were selected on the basis of the results of the blue-white screening procedure (50).

Sequencing of $16 \mathrm{~S}$ rDNA. Plasmids containing $16 \mathrm{~S}$ rDNA were isolated by using the standard purification method recommended by the manufacturer (Promega Co.). Purified plasmids were sequenced by using a Taq DyeDeoxy Terminator Cycle sequencing kit (Applied Biosystems, Foster City, Calif.). Sequencing gel electrophoresis was performed and nucleotide sequences were automatically obtained by using an Applied Biosystems model 373A DNA sequencer and the protocol and software recommended by the manufacturer. Sequence data were recorded on an IBM PC disk. The following forward and reverse primers were used (E. coli numbering system [7]): universal M13 forward-reverse primer $\mathrm{p} 125 \mathrm{f}$ (5'-GAA CGG GTG AGT AAC ACG T-3'; positions 107 to 125), p346f (5'ACG GCC CAG ACT CCT ACG-3'; positions 329 to 346), p357f (5'-CTA CGG
GRS GCA GCA G-3'; positions 342 to 357 ), p692f (5'-AAT TCC TGG TGT AGC GGT-3'; positions 675 to 692), p782r (5'-ACC AGG GTA TCT AAT CCT GT-3'; positions 801 to 782), p926f (5'-AAA CTC AAA GGA ATT GAC GG-3'; positions 907 to 926), and p1208f (5'-GAC GTC AAG TCA TCA TGC C-3'; positions 1190 to 1208 ). The nucleotide sequences of the sequencing primers were obtained from Lane (29) or were specifically designed for actinomycetes.

Phylogenetic analysis. The 16S rRNA gene sequences which we obtained were aligned manually with sequences of representative mycolic acid-containing actinomycetes (Table 1) obtained from the Ribosomal Database Project (release 4) (30) by using the AL16S program (10) to determine information concerning secondary structures.

An evolutionary distance matrix was constructed by using the algorithm of Jukes and Cantor (26). Phylogenetic trees were constructed by using the FitchMargoliash (17) and neighbor-joining (49) methods. Arthrobacter globiformis DSM $20124^{\mathrm{T}}$ ( $\mathrm{T}=$ type strain) was used as the outgroup in each of these analyses. In order to determine the stability of our phylogenetic tree, the sequence data were sampled 1,000 times for bootstrap analysis (15) by using the SEQBOOT program (PHYLIP, version 3.5c [16]).

Nucleotide sequence accession numbers. The 16S rDNA sequences which we determined in this study have been deposited in the EMBL database under the accession numbers listed in Table 1 . The accession numbers of the Mycobacterium nucleotide sequences that were compared with Nocardia sequences in this study are as follows: Mycobacterium aichiense, X55598; $M$. asiaticum, X55604; $M$. aurum, X55595; M. avium, M61673, M61672, M61671, M29573, M29572, X52918, X52934, M61668, M61669, M61670, and M61667; M. bovis BCG, M20940; $M$. bovis vallee, X55589; $M$. celatum, L08169 and L08170; M. chelonae, M29559 and X52921; $M$. chitae, X55603 and M61662; $M$. chubuense, X55596; $M$. confluentis, X63608; M. cookii, X53896; M. diernhoferi, X55593; M. fallax, M29562; M. farcinogenes, X55592; M. flavescens, X52932; M. fortuitum, X52933; M. gadium, X55594; M. gastri, X52919; M. geneveuse, X60070; M. gilvum, X55599; $M$. gordonae, X52923; M. haemophilum, L24800; M. hiberniae, X67096; M. intermedium, X67847; $M$. intracellulare, M61685, M61686, X52927, M61683, M61684, and M61682; M. kansasii, M29575 and X15916; M. komossense, X55591; $M$. leprae, X55587, X53999, and X55022; M. madagascariense, X55600; $M$. malmoense, X52930; $M$. marinum, X52920; $M$. neoaurum, M29564; $M$. nonchromogenicum, X52928; $M$. obuense, X55597; $M$. paratuberculosis, M29569, M61678, M61679, M61676, M61680, M61674, M61677, and M61675; $M$. phlei, M29566; $M$. scrofulaceum, X52924; $M$. senegalense, M29567; M. simiae, X52931; $M$. smegmatis, X52922; M. sphagni, X55590; M. szulgai, X52926; M. terrae, X52925; $M$. thermoresistibile, X55602; M. triviale, M29571; M. tuberculosis, X52917; M. ulcerans, Z13990 and X58954; M. vaccae, X55601; and M. xenopi, X52929. 
TABLE 2. Similarity values based on the $16 \mathrm{~S}$ rDNA sequences of Nocardia species and related mycolic acid-containing actinomycetes

\begin{tabular}{|c|c|c|c|c|c|c|c|c|c|c|c|c|c|c|c|c|c|c|c|c|}
\hline \multirow[b]{2}{*}{ Taxon } & \multicolumn{20}{|c|}{$\%$ Similarity to: } \\
\hline & 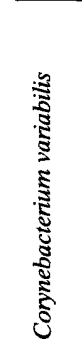 & 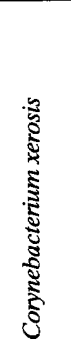 & 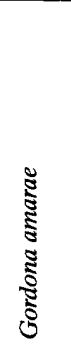 & 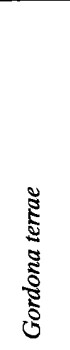 & 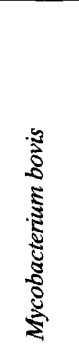 & 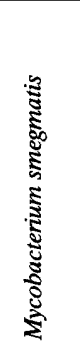 & 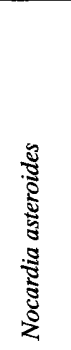 & 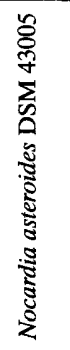 & 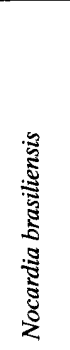 & 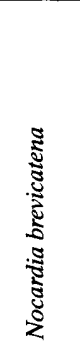 & 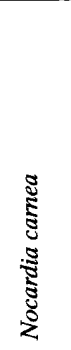 & 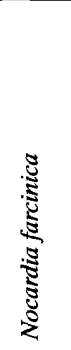 & 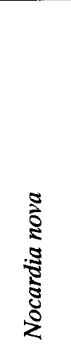 & 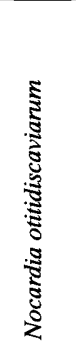 & 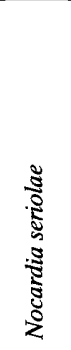 & 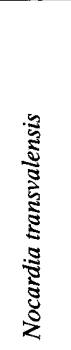 & 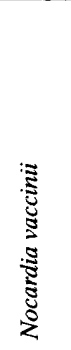 & 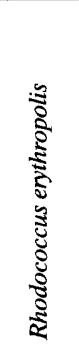 & 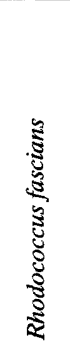 & 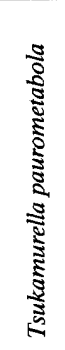 \\
\hline Corynebacterium variabilis & 100 & & & & & & & & & & & & & & & & & & & \\
\hline Corynebacterium $x$ & 95.21 & & & & & & & & & & & & & & & & & & & \\
\hline Gordona amarae & 90.8 & 91.31 & & & & & & & & & & & & & & & & & & \\
\hline Gordona terrae & 92.0 & 92.2 & 97.61 & 100 & & & & & & & & & & & & & & & & \\
\hline Mycobacterium bovis & 91.5 & 93.0 & 92.1 & 93.51 & 100 & & & & & & & & & & & & & & & \\
\hline Mycobacterium smegmatis & 91.0 & 91.7 & 93.5 & 93.8 & 96.01 & 100 & & & & & & & & & & & & & & \\
\hline Nocardia asteroides & 91.0 & 91.1 & 93.5 & 93.9 & 93.2 & 94.01 & 100 & & & & & & & & & & & & & \\
\hline Nocardia asteroides DSM 43005 & 90.8 & 91.3 & 93.4 & 94.4 & 92.6 & 93.9 & 98.41 & 100 & & & & & & & & & & & & \\
\hline Nocardia brasiliensis & 90.7 & 90.9 & 94.4 & 94.8 & 92.4 & 93.4 & 97.7 & 97.91 & 100 & & & & & & & & & & & \\
\hline Nocardia brevicatena & 90.4 & 90.8 & 93.0 & 93.6 & 93.0 & 94.4 & 97.4 & 97.9 & 96.51 & 100 & & & & & & & & & & \\
\hline Nocardia carnea & 91.2 & 91.2 & 92.9 & 93.6 & 93.2 & 94.2 & 98.0 & 98.3 & 97.0 & 97.81 & 100 & & & & & & & & & \\
\hline Nocardia farcinica & 91.8 & 91.8 & 93.9 & 94.6 & 92.5 & 93.8 & 97.6 & 98.0 & 98.0 & 96.3 & 96.71 & 100 & & & & & & & & \\
\hline Nocardia nova & 90.6 & 91.4 & 93.5 & 95.0 & 93.0 & 93.6 & 97.5 & 97.8 & 96.7 & 97.1 & 96.7 & 96.31 & 100 & & & & & & & \\
\hline Nocardia otitidiscaviarum & 90.6 & 91.1 & 92.7 & 94.4 & 93.2 & 93.5 & 96.9 & 97.7 & 96.3 & 96.8 & 96.6 & 96.0 & 98.41 & 100 & & & & & & \\
\hline Nocardia seriolae & 90.4 & 90.8 & 92.6 & 93.5 & 92.9 & 93.6 & 96.8 & 97.0 & 96.3 & 96.8 & 96.7 & 95.7 & 97.7 & 98.01 & 100 & & & & & \\
\hline Nocardia transvalensis & 91.0 & 91.7 & 93.9 & 94.8 & 92.7 & 93.5 & 97.4 & 97.9 & 97.7 & 96.8 & 96.9 & 97.9 & 97.5 & 96.9 & 96.3 & 100 & & & & \\
\hline Nocardia vaccinii & 91.5 & 91.4 & 93.0 & 94.4 & 93.1 & 94.0 & 97.1 & 97.1 & 96.1 & 97.4 & 96.8 & 96.7 & 98.2 & 97.5 & 97.5 & 97.11 & 100 & & & \\
\hline Rhodococcus erythropolis & 92.2 & 92.3 & 93.6 & 94.4 & 92.0 & 93.5 & 94.9 & 95.3 & 94.8 & 94.8 & 94.4 & 96.0 & 95.5 & 94.9 & 94.4 & 95.0 & & 100 & & \\
\hline Rhodococcus fascians & 91.5 & 91.2 & 91.7 & 93.1 & 91.8 & 91.9 & 93.6 & 93.5 & 93.0 & 92.8 & 93.3 & 93.7 & 94.3 & 94.0 & 93.5 & 93.4 & 94.1 & & 100 & \\
\hline Tsukamurella paurometabola & 92.2 & 92.5 & 94.4 & 94.0 & 92.9 & 94.5 & 94.4 & 94.0 & 94.0 & 93.4 & 93.8 & 94.6 & 93.8 & 93.4 & 93.6 & 94.1 & 93.8 & 94.8 & 92.5 & 100 \\
\hline
\end{tabular}

\section{RESULTS AND DISCUSSION}

Mycolic acid-containing organisms are classified in the families Corynebacteriaceae (34), Mycobacteriaceae (9), and Nocardiaceae (8); the family Nocardiaceae currently contains the genera Gordona, Nocardia, Rhodococcus, and Tsukamurella (18). It is evident from the phylogenetic tree derived from the sequence similarity values (Table 2 ) that the genus Nocardia, the type genus of the family Nocardiaceae, forms a distinct phyletic line that is most closely related to the genus Rhodococcus (Fig. 1). The average level of sequence similarity between representative nocardiae and rhodococci was $94.3 \%$. The Gordona branch joins the Nocardia-Rhodococcus group, albeit at nonsignificant bootstrap values. The branching order of the Mycobacterium and Tsukamurella lines is not clear, as discordant results were found with the two methods used to generate the phylogenetic trees.

Our sequence data confirm and extend the results of Ruimy et al. (48), which were based on analyses of small-subunit rDNA sequences; however, our results also raise questions. In particular, the close relationship between $N$. farcinica and Rhodococcus equi found by Ruimy et al. seems to be questionable. When more nucleotides of the 16S rRNA of the type strain of $N$. farcinica are compared, this organism is clearly placed in the Nocardia clade.

The nocardiae were assigned to two rRNA subgroups, one corresponding to $N$. asteroides and related taxa and the other corresponding to Nocardia otitidiscaviarum and allied species (Fig. 1). The taxonomic significance of these subgroups is supported by the $100 \%$ bootstrap values based on 1,000 samplings. The separation of the nocardiae into two subgroups is based largely on differences found in helix 37-1 (42), as shown in Fig.
2. In this present study, almost complete 16S rRNA gene sequences $(1,472$ to 1,474 nucleotides) were determined. The sequences of two other nocardiae, $N$. asteroides DSM 43005 and $N$. otitidiscaviarum ATCC $14629^{\mathrm{T}}$, were generated by Rogall et al. (47) and Yang and Woese (57), respectively.

The six species belonging to the $N$. asteroides subgroup include $N$. asteroides, Nocardia brevicatena, and Nocardia carnea. Members of these taxa either are human pathogens or have been implicated as human pathogens $(5,18,19,23,51)$. The close genotypic affinities among $N$. asteroides, $N$. brevicatena, and $N$. carnea are at variance given the phenotypic similarities of $N$. asteroides, $N$. farcinica, and $N$. nova strains found by Wallace et al. (55). While these latter species are readily separated by $16 \mathrm{~S}$ rDNA sequence data, they are difficult to distinguish on the basis of simple phenotypic properties $(5,18,19$, 55 ). It is also interesting that the remaining members of the $N$. asteroides subgroup (namely, $N$. brasiliensis, $N$. farcinica, and $N$. transvalensis) are closely related on the basis of nucleotide sequence data. Members of all of these taxa cause actinomycete mycetoma or have been implicated as agents of actinomycete mycetoma $(19,35,36,38)$.

The second taxon, the $N$. otitidiscaviarum subgroup, consists of four species (Fig. 1). $N$. otitidiscaviarum and $N$. nova cause nocardiosis $(5,51,55)$, and Nocardia seriolae is pathogenic for cultured fish (28). N. nova is an important pathogen (55) which has been separated from $N$. asteroides and $N$. farcinica strains on the basis of results of DNA relatedness analyses $(28,58)$ and mycolic acid analyses (58). Separation of these taxa on the basis of 16S rDNA sequence data is important as it paves the way for the development of PCR or oligonucleotide probes for diagnostic purposes $(3,14)$. The sharp separation of the type 


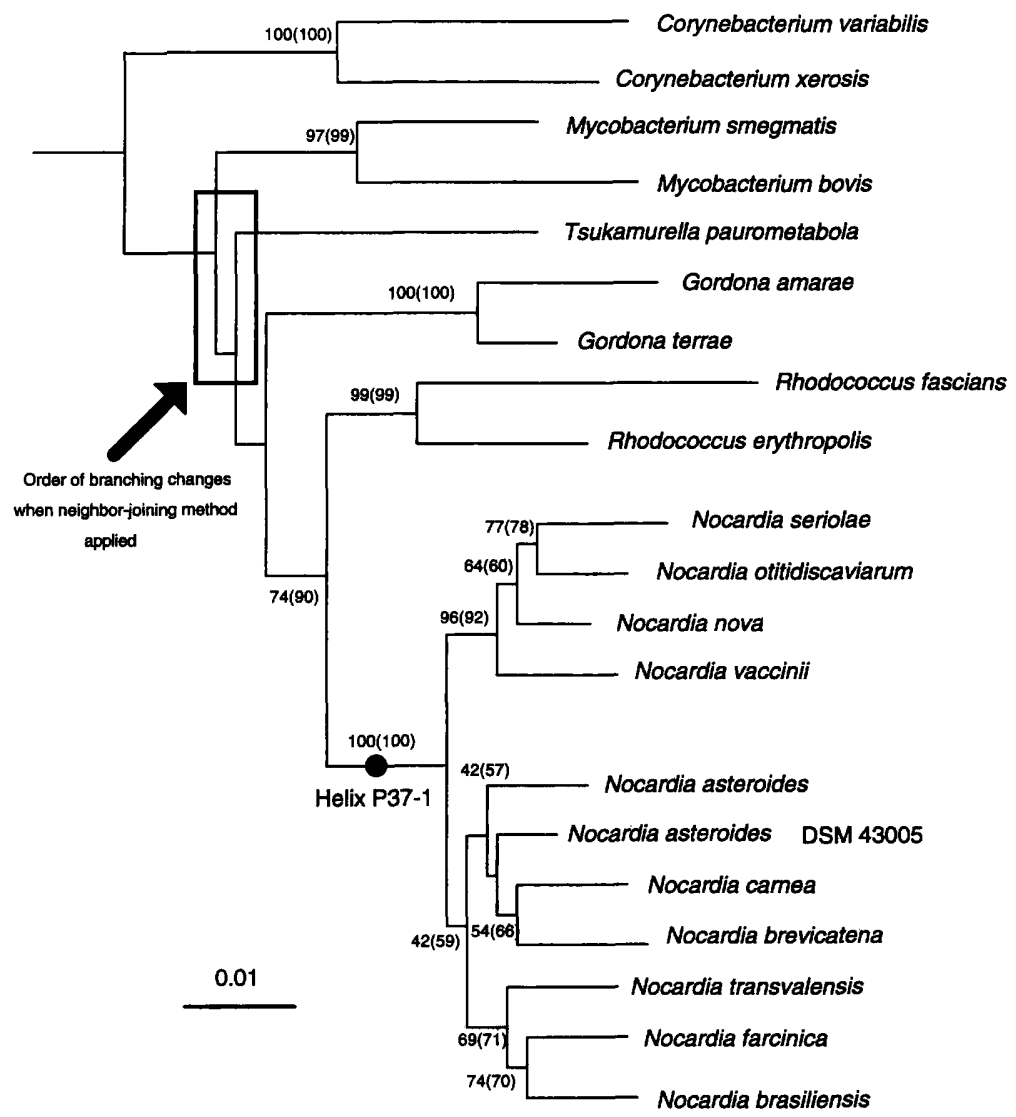

FIG. 1. Phylogenetic tree showing the relationships among Nocardia species and between nocardiae and representatives of other mycolic acid-containing taxa. The tree was constructed by using the method of Fitch and Margoliash (17). The numbers at the nodes indicate the levels of bootstrap support based on data for 1,000 replicates; only values that are greater than $50 \%$ are shown. Bootstrap values derived from the neighbor-joining method (49) are given in parentheses. The scale bar indicates 0.01 substitution per nucleotide position. For additional details see the text.

strains of $N$. asteroides and $N$. farcinica (level of sequence similarity, $97.6 \%$ ) is consistent with the results of DNA relatedness $(40,41)$, numerical phenetic $(27,43,52,54)$, and serological (46) studies.

The average level of sequence similarity found among the type strains of Nocardia species was $97.2 \% \pm 0.7 \%$. The closest association was found between $N$. otitidiscaviarum and $N$. nova (level of similarity, 98.4\%), and the most distant association

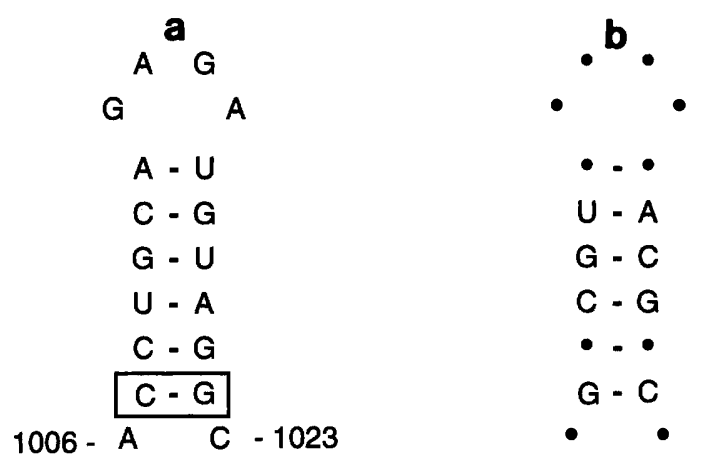

FIG. 2. Signatures that distinguish the two rRNA subgroups found in the genus Nocardia. The P37-1 helix (42) lies between $E$. coli nucleotide positions 1006 and 1023 (7). The pair of nucleotides enclosed in a box is G-C in $N$. transvalensis. (a) $N$. asteroides rRNA subgroup. (b) $N$. otitidiscaviarum rRNA subgroup. was observed between $N$. farcinica and $N$. seriolae (level of similarity, $95.7 \%$ ). These relatively modest levels of similarity are consistent with the low DNA complementary values ( 7 to $18 \%$ ) reported between representatives of these taxa (28). The 16 SDNA nucleotide signatures that distinguish the Nocardia species are shown in Table 3 . It is also interesting that the levels of 16S rDNA similarity found within the genus Nocardia are slightly greater than the values recorded for members of the genus Mycobacterium $(45,47,53)$. There are several nucleotide signatures that distinguish Nocardia and Mycobacterium strains (Table 4).

It is evident that the genus Nocardia now constitutes a homogeneous taxon that can be distinguished from other mycolic acid-containing organisms on the basis of chemical, morphological, and 16S rDNA sequence data. The results of our isoprenoid quinone analyses provide evidence that nocardiae can be distinguished from all other actinomycetes, including corynebacteria, gordonae, mycobacteria, rhodococci, and tsukamurellae, on the basis of their characteristic menaquinone profiles. Our data confirm and extend the results of previous studies $(13,25,27)$ and show that nocardiae typically contain hexahydrogenated menaquinones with eight isoprene units in which the two end units are cyclized $\left[\mathrm{MK}-8\left(\mathrm{H}_{4}\right) \mathrm{c}\right]$. The discovery that the type strains of $N$. nova, $N$. seriolae, and Nocardia vaccinii contain major amounts of this compound is further evidence that these organisms are members of the genus Nocardia. In all 10 of the test strains the MK- $8\left(\mathrm{H}_{4}\right) \mathrm{c}$ 
TABLE 3. $16 \mathrm{~S}$ rDNA sequence signatures that differentiate Nocardia species

\begin{tabular}{|c|c|c|c|c|c|c|c|c|c|c|c|}
\hline Positions $^{a}$ & N. asteroides & $\begin{array}{c}N . \\
\text { asteroides } \\
\text { DSM 43005 }\end{array}$ & N. brasiliensis & N. brevicatena & N. carnea & N. farcinica & $N$. nova & $\begin{array}{l}\text { N. otitidis- } \\
\text { caviarum }\end{array}$ & $N$. seriolae & $\begin{array}{l}\text { N. trans- } \\
\text { valensis }\end{array}$ & N. vaccinii \\
\hline $137: 226$ & $\mathrm{U}: \mathrm{A}$ & U:A & U:A & U:A & U:A & C:G & U:A & U:A & U:A & U:A & U:A \\
\hline 199:218 & $\mathrm{A}: \mathrm{U}$ & $\mathrm{A}: \mathrm{U}$ & A:U & A:U & A:U & A:U & A:U & G:C & A:U & A:U & $A: U$ \\
\hline $258: 268$ & $\mathrm{G}: \mathrm{C}$ & $\mathrm{G}: \mathrm{C}$ & $\mathrm{G}: \mathrm{C}$ & $\mathrm{G}: \mathrm{C}$ & $\mathrm{G}: \mathrm{C}$ & $\mathrm{G}: \mathrm{C}$ & $\mathrm{G}: \mathrm{C}$ & G:C & A:U & G:C & G:C \\
\hline 293:304 & $\mathrm{G}: \mathrm{C}$ & G:C & A:U & G:C & $\mathrm{G}: \mathrm{C}$ & G:C & $\mathrm{A}: \mathrm{U}$ & $\mathrm{G}: \mathrm{C}$ & $\mathrm{G}: \mathrm{C}$ & $\mathrm{G}: \mathrm{C}$ & G:C \\
\hline $407: 435$ & A:U & $\mathrm{A}: \mathrm{U}$ & A:U & A:U & A:U & $\mathrm{A}: \mathrm{U}$ & $\mathrm{A}: \mathrm{U}$ & $\mathrm{A}: \mathrm{U}$ & $\mathrm{A}: \mathrm{U}$ & C:G & $A: U$ \\
\hline $444: 490$ & A:U & $A: U$ & $\mathrm{~A}: \mathrm{U}$ & $A: U$ & U:A & $\mathrm{A}: \mathrm{U}$ & $\mathrm{A}: \mathrm{U}$ & $\mathrm{A}: \mathrm{U}$ & A:U & $\mathrm{A}: \mathrm{U}$ & $\mathrm{A}: \mathrm{U}$ \\
\hline 445:489 & G:C & $\mathrm{G}: \mathrm{C}$ & G:C & G:C & C:G & G:C & G:C & $\mathrm{G}: \mathrm{C}$ & $\mathrm{G}: \mathrm{C}$ & $\mathrm{G}: \mathrm{C}$ & $\mathrm{G}: \mathrm{C}$ \\
\hline $446: 488$ & $\mathrm{G}: \mathrm{C}$ & $\mathrm{G}: \mathrm{C}$ & $\mathrm{G}: \mathrm{C}$ & $\mathrm{G}: \mathrm{C}$ & $\mathrm{C}: \mathrm{G}$ & $\mathrm{G}: \mathrm{C}$ & G:C & $\mathrm{G}: \mathrm{C}$ & G:C & G:C & $\mathrm{G}: \mathrm{C}$ \\
\hline 591:648 & $\mathrm{C}: \mathrm{G}$ & U:A & U:A & $\mathrm{U}: \mathrm{A}$ & $\mathrm{U}: \mathrm{A}$ & U:A & C:G & U:A & U:A & U:A & C:G \\
\hline 603:635 & $\mathrm{C}: \mathrm{G}$ & $\mathrm{C}: \mathrm{G}$ & $\mathrm{C}: \mathrm{G}$ & C:G & C:G & $C: G$ & U:A & $\mathrm{C}: \mathrm{G}$ & $\mathrm{C}: \mathrm{G}$ & $\mathrm{C}: \mathrm{G}$ & C:G \\
\hline $614: 626$ & $\mathrm{G}: \mathrm{C}$ & $\mathrm{G}: \mathrm{C}$ & $\mathrm{G}: \mathrm{C}$ & $A: U$ & G:C & $\mathrm{G}: \mathrm{C}$ & $\mathrm{G}: \mathrm{C}$ & $\mathrm{G}: \mathrm{C}$ & $\mathrm{A}: \mathrm{U}$ & G:C & $\mathrm{A}: \mathrm{U}$ \\
\hline $615: 625$ & $\mathrm{G}: \mathrm{C}$ & $\mathrm{G}: \mathrm{C}$ & G:C & $\mathrm{C}: \mathrm{G}$ & G:C & $\mathrm{G}: \mathrm{C}$ & C:G & C:G & C:G & G:C & C:G \\
\hline $616: 624$ & $\mathrm{G}: \mathrm{C}$ & $\mathrm{G}: \mathrm{C}$ & G:C & A:U & $\mathrm{G}: \mathrm{C}$ & $\mathrm{G}: \mathrm{C}$ & $\mathrm{A}: \mathrm{U}$ & $\mathrm{A}: \mathrm{U}$ & $\mathrm{A}: \mathrm{U}$ & G:C & $\mathrm{A}: \mathrm{U}$ \\
\hline $824: 876$ & U:A & U:A & U:A & U:A & U:A & C:G & $\mathrm{U}: \mathrm{A}$ & U:A & U:A & U:A & C:G \\
\hline $825: 875$ & $\mathrm{~A}: \mathrm{U}$ & A:U & $\mathrm{A}: \mathrm{U}$ & A:U & A:U & $\mathrm{G}: \mathrm{C}$ & $\mathrm{A}: \mathrm{U}$ & $\mathrm{A}: \mathrm{U}$ & $\mathrm{A}: \mathrm{U}$ & A:U & G:C \\
\hline 1002:1038 & G:C & $\mathrm{G}: \mathrm{C}$ & $\mathrm{G}: \mathrm{C}$ & G:C & G:C & G:C & A:U & G:C & G:C & $\mathrm{A}: \mathrm{U}$ & $\mathrm{A}: \mathrm{U}$ \\
\hline $1007: 1022$ & $\mathrm{C}: \mathrm{G}$ & C:G & C:G & $\mathrm{C}: \mathrm{G}$ & C:G & $\mathrm{C}: \mathrm{G}$ & G:C & $\mathrm{G}: \mathrm{C}$ & $\mathrm{G}: \mathrm{C}$ & G:C & G:C \\
\hline $1009: 1020$ & $\mathrm{U}: \mathrm{A}$ & U:A & U:A & U:A & U:A & U:A & C:G & $C: G$ & $C: G$ & U:A & $C: G$ \\
\hline 1011:1018 & C:G & C:G & C:G & C:G & C:G & C:G & U:A & U:A & U:A & C:G & U:A \\
\hline $1120: 1153$ & U:A & U:A & $\mathrm{C}: \mathrm{G}$ & U:A & U:A & C:G & U:A & U:A & U:A & $\mathrm{C}: \mathrm{G}$ & U:A \\
\hline $1122: 1151$ & A:U & A:U & G:C & A:U & A:U & $\mathrm{G}: \mathrm{C}$ & $\mathrm{A}: \mathrm{U}$ & A:U & A:U & G:C & A:U \\
\hline $1134: 1140$ & $\mathrm{C}: \mathrm{G}$ & C:G & $\mathrm{G}: \mathrm{C}$ & $C: G$ & $C: G$ & $\mathrm{C}: \mathrm{G}$ & $\mathrm{C}: \mathrm{G}$ & C:G & C:G & C:G & $\mathrm{C}: \mathrm{G}$ \\
\hline
\end{tabular}

${ }^{a}$ E. coli numbering (7).

component accounted for more than $90 \%$ of the total menaquinones.

Our results highlight the power of $16 \mathrm{~S}$ rDNA sequencing for determining relationships between organisms that have proved to be difficult to classify by more conventional methods. This approach, together with the use of appropriate chemical and morphological methods, should prove to be sufficiently powerful to determine relationships in the well-known taxonomic enigma called the "Nocardia asteroides complex" $(18,43)$.

\section{ACKNOWLEDGMENTS}

Jongsik Chun is grateful to the British Council (Seoul, Korea). We are also indebted to R. M. Liddell for technical support and to the Ribosomal Database Project for access to aligned sequence data.

TABLE 4. Nucleotide signatures that distinguish Mycobacterium and Nocardia strains

\begin{tabular}{ccc}
\hline Position(s) $^{a}$ & Mycobacterium $^{b}$ & Nocardia \\
\hline $66: 103$ & A:U & G:C \\
328 & $\mathrm{U}$ & $\mathrm{C}$ \\
$580: 761$ & $\mathrm{C}: \mathrm{G}$ & $\mathrm{U}: \mathrm{A}$ \\
694 & $\mathrm{G}$ & $\mathrm{A}$ \\
$998: 1043$ & $\mathrm{G}: \mathrm{U}$ & $\mathrm{A}: \mathrm{U}$ \\
$1001: 1039$ & $\mathrm{~A}: \mathrm{U}$ & $\mathrm{C}: \mathrm{G}$ \\
$1003: 1037$ & $\mathrm{G}: \mathrm{C}$ & $\mathrm{G}: \mathrm{U}$ \\
1189 & $\mathrm{U}$ & $\mathrm{C}$ \\
1336 & $\mathrm{C}$ & $\mathrm{U}$ \\
\hline
\end{tabular}

${ }^{a} E$. coli numbering (7)

${ }^{b}$ Based on sequence data from Mycobacterium aichiense, $M$. asiaticum, $M$. aurum, $M$. avium, $M$. bovis BCG, $M$. bovis vallee, $M$. celatum, $M$. chelonae, $M$. chitae, $M$. chubuense, $M$. confluentis, $M$. cookii, $M$. diernhoferi, $M$. fallax, $M$. farcinogenes, $M$. flavescens, $M$. fortuitum, $M$. gadium, $M$. gastri, $M$. geneveuse, $M$. gilvum, $M$. gordonae, $M$. haemophilum, $M$. hiberniae, $M$. intermedium, $M$. intracellulare, $M$. kansasii, $M$. komossense, $M$. leprae, $M$. madagascariense, $M$. malmoense, $M$. marinum, $M$. neoaurum, $M$. nonchromogenicum, $M$. obuense, $M$. paratuberculosis, $M$. phlei, $M$. scrofulaceum, $M$. senegalense, $M$. simiae, $M$. smegmatis, $M$. sphagni, M. szulgai, $M$. terrae, $M$. thermoresistibile, $M$. triviale, $M$. tuberculosis, $M$. ulcerans, $M$. vaccae, and $M$. xenopi.

\section{REFERENCES}

1. Berkey, P., D. Moore, and K. Rolston. 1988. In vitro susceptibilities of Nocardia species to newer antimicrobial agents. Antimicrob. Agents Chemother. 32:1078-1079.

2. Blackall, L. L., J. H. Parlett, A. C. Hayward, D. E. Minnikin, P. F. Greenfield, and A. Harbers. 1989. Nocardia pinensis sp. nov., an actinomycete found in activated sludge foams in Australia. J. Gen. Microbiol. 135:15471558.

3. Böddinghaus, B., T. Rogall, T. Flohr, H. Blöcker, and E. C. Böttger. 1990. Detection and identification of mycobacteria by amplification of rRNA. J. Clin. Microbiol. 28:1751-1759.

4. Boiron, P., and F. Provost. 1988. In vitro susceptibility testing of Nocardia spp. and its taxonomic implications. J. Antimicrob. Chemother. 22:623-629.

5. Boiron, P., F. Provost, and B. Duport. 1993. Laboratory methods for the diagnosis of nocardiosis. Institut Pasteur, Paris.

6. Bowden, G. H., and M. Goodfellow. 1990. The actinomycetes: Actinomyces, Nocardia and related genera, p. 31-57. In M. T. Parker and B. I. Duerden (ed.), Topley and Wilson's principles of bacteriology, virology and immunity, 8th ed., vol. 4. Edward Arnold, London.

7. Brosius, J., M. L. Palmer, P. J. Kennedy, and H. F. Noller. 1978. Complete nucleotide sequence of a 16S ribosomal RNA gene from Escherichia coli. Proc. Natl. Acad. Sci. USA 75:4801-4805.

8. Castellani, A., and A. J. Chalmers. 1919. Manual of tropical medicine, 3rd ed. William, Wood and Co., New York.

9. Chester, F. D. 1897. Report of the mycologist: bacteriological work. Del. Agric. Exp. Stn. Bull. 9:38-145.

10. Chun, J. Unpublished data.

11. Chun, J., L. L. Blackall, and M. Goodfellow. Unpublished data.

12. Chun, J., and M. Goodfellow. Unpublished data.

13. Collins, M. D., O. W. Howarth, E. Grund, and R. M. Kroppenstedt. 1987. Isolation and structural determination of new members of the vitamin K2 series in Nocardia brasiliensis. FEMS Microbiol. Lett. 41:35-39.

14. DeLong, E. F., G. S. Wickham, and N. R. Pace. 1989. Phylogenetic strains: ribosomal RNA-based probes for the identification of single microbial cells. Science 243:1360-1363.

15. Felsenstein, J. 1985. Confidence limits on phylogenies: an approach using the bootstrap. Evolution 39:783-791.

16. Felsenstein, J. 1993. PHYLIP (phylogenetic inference package) version 3.5c. Department of Genetics, University of Washington, Seattle.

17. Fitch, W. M., and E. Margoliash. 1967. Construction of phylogenetic trees: a method based on mutation distances as estimated from cytochrome $\mathrm{c}$ sequences is of general applicability. Science 155:279-284.

18. Goodfellow, M. 1992. The family Nocardiaceae, p. 1188-1213. In A. Balows, H. G. Trüper, M. Dworkin, W. Harder, and K. H. Schleifer (ed.), The prokaryotes, 2nd ed. Springer Verlag, New York.

19. Goodfellow, M. Actinomycetes: Actinomyces, Actinomadura, Nocardia, Streptomyces and related taxa. In J. P. Collee, J. P. Duguid, A. G. Fraser, B. P. 
Marmion, and A. Simmons (ed.), Mackie and McCartney practical medical microbiology, 14th ed., in press. Churchill Livingstone, Edinburgh.

20. Goodfellow, M., J. Chun, S. Stubbs, and A. S. Toboli. 1994. Transfer of Nocardia amarae Lechevalier and Lechevalier to the genus Gordona as Gordona amarae comb. nov. Lett. Appl. Microbiol. 19:401-405.

21. Goodfellow, M., and M. P. Lechevalier. 1989. Genus Nocardia Trevisan 1889 $9^{\mathrm{AL}}$, p. 2350-2361. In S. T. Williams, M. E. Sharpe, and J. G. Holt (ed.), Bergey's manual of systematic bacteriology, vol. 4. The Williams \& Wilkins Co., Baltimore.

22. Gordon, R. E., and J. M. Mihm. 1962. Identification of Nocardia caviae comb. nov. Ann. N. Y. Acad. Sci. 98:628-639.

23. Gordon, R. E., S. K. Mishra, and D. A. Barnett. 1978. Some bits and pieces of the genus Nocardia: $N$. carnea, $N$. vaccinii, $N$. transvalensis, $N$. orientalis and $N$. aerocolonigenes. J. Gen. Microbiol. 109:69-78.

24. Heery, D. M., F. Gannon, and R. Powell. 1990. A simple method for subcloning DNA fragments from gel slices. Trends Genet. 6:173.

25. Howarth, O. W., E. Grund, R. M. Kroppenstedt, and M. D. Collins. 1986. Structural determination of a new naturally occurring cyclic vitamin K. Biochem. Biophys. Res. Commun. 140:916-923.

26. Jukes, T. H., and C. R. Cantor. 1969. Evolution of protein molecules, p. 21-132. In H. N. Munro (ed.), Mammalian protein metabolism. Academic Press, New York.

27. Kämpfer, P., W. Dott, and R. M. Kroppenstedt. 1990. Numerical classification and identification of some nocardioform bacteria. J. Gen. Appl. Microbiol. 36:309-331.

28. Kudo, T., K. Hatai, and A. Seino. 1988. Nocardia seriolae sp. nov. causing nocardiosis of cultured fish. Int. J. Syst. Bacteriol. 38:173-178.

29. Lane, D. J. 16S/23S rRNA sequencing, p. 115-175. In E. Stackebrandt and M. Goodfellow (ed.), Nucleic acid techniques in bacterial systematics. John Wiley and Sons, Chichester, United Kingdom.

30. Larsen, N., G. J. Olsen, B. L. Maidak, M. J. McCaughey, R. Overbeek, T. J. Macke, T. L. Marsh, and C. R. Woese. 1993. The Ribosomal Database Project. Nucleic Acids Res. 21:3021-3023.

31. Lechevalier, M. P. 1976. The taxonomy of the genus Nocardia, p. 1-38. In M. Goodfellow, G. H. Brownell, and J. A. Serrano (ed.), The biology of the nocardiae. Academic Press, London.

32. Lechevalier, M. P., and H. A. Lechevalier. 1970. A critical evaluation of the genera of aerobic actinomycetes, p. 393-405. In H. Prauser (ed.), The Actinomycetales. Gustav-Fischer Verlag, Jena, Germany.

33. Lechevalier, M. P., and H. A. Lechevalier. 1974. Nocardia amarae sp. nov., an actinomycete common in foaming activated sludge. Int. J. Syst. Bacteriol. 24:278-288.

34. Lehmann, K. B., and R. Neumann. 1986. Atlas und Grundriss der Bakteriologie und Lehrbuch der speciellen bakteriologischen Diagnostik, Teil II. J. F. Lehmann, Munich.

35. McNeil, M., and J. M. Brown. 1994. The medically important actinomycetes: epidemiology and microbiology. Clin. Microbiol. Rev. 7:357-417.

36. McNeil, M. J. M. Brown, P. R. Georghiou, A. M. Allworth, and Z. M. Blacklock. 1992. Infections due to Nocardia transvalensis: clinical spectrum and antimicrobial therapy. Clin. Infect. Dis. 15:453-463.

37. Minnikin, D. E., A. G. O'Donnell, M. Goodfellow, G. Alderson, M. Athalye, A. Schaal, and J. H. Parlett. 1984. An integrated procedure for the extraction of isoprenoid quinones and polar lipids. J. Microbiol. Methods 2:233241.

38. Mirza, S. H., and C. Campbell. 1994. Mycetoma caused by Nocardia transvalensis. J. Clin. Pathol. 47:85-86.
39. Mordarska, H., M. Mordarski, and M. Goodfellow. 1972. Chemotaxonomic characters and classification of some nocardioform bacteria. J. Gen. Microbiol. 71:77-86.

40. Mordarski, M., K. P. Schaal, K. Szyba, G. Pulverer, and A. Tkacz. 1977. Interrelation of Nocardia asteroides and related taxa as indicated by deoxyribonucleic acid reassociation. Int. J. Syst. Bacteriol. 27:66-70.

41. Mordarski, M., K. P. Schaal, A. Tkacz, G. Pulverer, K. Szyba, and M. Goodfellow. 1978. Deoxyribonucleic acid base composition and homology studies on Nocardia. Zentralbl. Bakteriol. Suppl. 6:91-97.

42. Neefs, J.-M., Y. V. de Peer, P. De Rijk, S. Chapelle, and R. De Wachter. 1993. Compilation of small ribosomal subunit RNA structures. Nucleic Acids Res. 21:3025-3049.

43. Orchard, V. A., and M. Goodfellow. 1980. Numerical classification of some named strains of Nocardia asteroides and related isolates from soil. J. Gen. Microbiol. 118:295-312.

44. Pitcher, D. G., N. A. Saunders, and R. J. Owen. 1989. Rapid extraction of bacterial genomic DNA with guanidium thiocyanate. Lett. Appl. Microbiol. 8:151-156.

45. Pitulle, C., M. Dorsch, J. Kazda, J. Wolters, and E. Stackebrandt. 1992. Phylogeny of rapidly growing members of the genus Mycobacterium. Int. J. Syst. Bacteriol. 42:337-343.

46. Ridell, M. 1975. Taxonomic study of Nocardia farcinica using serological and physiological characters. Int. J. Syst. Bacteriol. 25:124-132.

47. Rogall, T., J. Wolters, T. Flohr, and E. C. Böttger. 1990. Towards a phylogeny and definition of species at the molecular level within the genus Mycobacterium. Int. J. Syst. Bacteriol. 40:323-330.

48. Ruimy, R., P. Boiron, V. Boivin, and R. Christen. 1994. A phylogeny of the genus Nocardia deduced from the analysis of small-subunit ribosomal DNA sequences, including transfer of Nocardia amarae to the genus Gordona as Gordona amarae comb. nov. FEMS Microbiol. Lett. 123:261-268.

49. Saitou, N., and M. Nei. 1987. The neighbor joining method: a new method for constructing phylogenetic trees. Mol. Biol. Evol. 4:406-425.

50. Sambrook, J., E. F. Fritsch, and T. Maniatis. 1989. Molecular cloning: a laboratory manual, 2nd ed. Cold Spring Harbor Laboratory Press, Cold Spring Harbor, N.Y.

51. Schaal, K. P., and H. J. Lee. 1992. Actinomycete infections in humans-a review. Gene 151:201-211.

52. Schaal, K. P., and H. Reutersberg. 1978. Numerical taxonomy of Nocardia asteroides, p. 53-62. In M. Mordarski, W. Kurylowicz, and J. Jeljaszewicz (ed.), Nocardia and Streptomyces. Gustav-Fischer Verlag, Stuttgart, Germany.

53. Stahl, D. A., and J. W. Urbance. 1990. The division between fast- and slow-growing species corresponds to natural relationships among the mycobacteria. J. Bacteriol. 172:116-124.

54. Tsukamura, M. 1969. Numerical taxonomy of the genus Nocardia. J. Gen. Microbiol. 56:265-287.

55. Wallace, R. J., Jr., B. A. Brown, M. Tsukamura, J. M. Brown, and G. O. Onyi. 1991. Clinical and laboratory features of Nocardia nova. J. Clin. Microbiol. 29:2407-2411.

56. Wallace, R. J., Jr., L. C. Steele, G. Sumter, and J. M. Smith. 1988. Antimicrobial susceptibility patterns of Nocardia asteroides. Antimicrob. Agents Chemother. 32:1776-1779.

57. Yang, D., and C. R. Woese. Unpublished data.

58. Yano, I., T. Imaeda, and M. Tsukamura. 1990. Characterization of Nocardia nova. Int. J. Syst. Bacteriol. 40:170-174. 